\title{
NUTRITIONAL EVALUATION OF TILAPIA FILLETING WASTE MEAL FOR SWINE IN THE NURSERY PHASE ${ }^{1}$
}

\author{
EDSON RICHART*2, RICARDO VIANNA NUNES ${ }^{2}$, LEANDRO DALCIN CASTILHA ${ }^{3}$, YOLANDA LOPES DA \\ SILVA $^{2}$, PAULO SEGATTO CELLA ${ }^{4}$
}

\begin{abstract}
Three experiments were conducted to determine the nutritional composition of tilapia filleting waste meal (TFWM) for pigs in the initial phase. In the first experiment, the chemical composition and the values of digestible and metabolizable energy of TFWM were determined using 10 pigs $(15.10 \pm 0.74 \mathrm{~kg})$, distributed in cages for metabolic research (2 treatments X 5 replicates). The TFWM replaced $20 \%$ of the reference diet based on corn and soybean meal. In the second experiment, the ileal digestibility coefficients of amino acids present in TFWM were determined, using chromic oxide as a marker, through the method of sacrifice, using 10 pigs $(15.00 \pm 0.27 \mathrm{~kg})$, distributed in cages for metabolic research $(2$ treatments X 5 replicates). Treatments consisted of a basal diet and one without protein. In the third experiment, the performance of pigs fed diets containing different concentrations of TFWM (0, 5, 10, 15 and 20\%) was evaluated. Forty pigs $(15.00 \pm 0.87 \mathrm{~kg})$, distributed in pairs in nursery pens ( 5 treatments $\mathrm{X} 4$ replicates $)$ were used. The values of digestible and metabolizable energy corresponded to 3,632 and 3,260 kcal $/ \mathrm{kg}$, respectively. Inclusion of up to $10 \%$ TFWM in the diet of barrows from 15 to $30 \mathrm{~kg}$ did not affect the average daily gain and feed conversion of the animals.
\end{abstract}

Keywords: Alternative feed. Energy values. Digestible amino acids.

\section{AVALIAÇÃO NUTRICIONAL DA FARINHA RESIDUAL DE FILETAGEM DA TILÁPIA PARA SUÍNOS EM FASE DE CRECHE}

RESUMO - Foram realizados três experimentos para determinar a composição nutricional da farinha dos resíduos industriais de filetagem da tilápia (FRIFT) para suínos, machos castrados, em fase inicial. No primeiro, foi determinada a composição bromatológica e valores de energia digestível e metabolizável da FRIFT, utilizando-se 10 suínos $(15,10 \mathrm{~kg} \pm 0,74)$, distribuídos em gaiolas para estudos metabólicos (2 tratamentos X 5 repetições). A FRIFT substituiu em $20 \%$ a ração referência, à base de milho e farelo de soja. No segundo experimento, foram determinados os coeficientes de digestibilidade ileal dos aminoácidos da FRIFT, empregando-se óxido crômico como indicador, pelo método do sacrifício, tendo sido utilizados 10 suínos $(15,00 \mathrm{~kg} \pm 0,27)$, distribuídos em gaiolas para estudos metabólicos ( 2 tratamentos X 5 repetições). Os tratamentos consistiram de uma ração basal e outra sem proteína. No terceiro experimento, foi avaliado o desempenho de suínos alimentados com rações contendo diferentes níveis de FRIFT (0, 5, 10, 15 e $20 \%$ ). Foram utilizados 40 suínos $(15,00 \mathrm{~kg} \pm 0,87)$, distribuídos aos pares em baias de creche $(5$ tratamentos X 4 repetições). Os valores de energia digestível e metabolizável corresponderam a 3.632 e $3.260 \mathrm{kcal} / \mathrm{kg}$, respectivamente. A inclusão de até 10 \% de FRIFT na dieta de suínos machos castrados, dos 15 aos $30 \mathrm{~kg}$, não alterou o ganho de peso diário e a conversão alimentar dos animais.

Palavras-chave: Alimentos alternativos. Valores energéticos. Aminoácidos digestíveis.

\footnotetext{
*Corresponding author

${ }^{1}$ Received for publication in $05 / 05 / 2014$; accepted in $01 / 27 / 2016$

Paper extracted from the master degree thesis of the first author.

${ }^{2}$ Department of Animal Science, Universidade Estadual do Oeste do Paraná, Marechal Cândido Rondon, PR, Brazil; edson.richart@yahoo.com,nunesrv@hotmail.com,ylopesdasilva@yahoo.com.br.

${ }^{3}$ Department of Animal Science, Universidade Estadual de Maringá, Maringá, PR, Brazil; leandrocastilha@hotmail.com.

${ }^{4}$ Department of Animal Science, Universidade Tecnológica Federal do Paraná, Dois Vizinhos, PR, Brazil; paulocella@hotmail.com.
} 


\section{INTRODUCTION}

Animal meal represents a sustainable option for the feeding of monogastric animals. However, some by-products present limitations due to a lack of standardization and regulation. For example, tilapia filleting waste meal (TFWM), which is composed of head, carcass and viscera, presents the potential for use in animal feeds (SCHEUERMANN; ROSA, 2008).

The fish processing industry generates large amounts of waste, which when not properly processed for use in human or animal nutrition, can be deposited in the environment, generating pollutants. This fact, combined with the scarcity and high market price of fishmeal derived from extractive fishing, has motivated research aimed at replacing standard fish meal (anchovy, mackerel, etc.) with alternative protein foods (RICHTER et al., 2003). In this context, TFWM is an ingredient with enormous potential to replace conventional fish meal in the feeding of monogastric animals. The TFWM basically consists of residual material after the removal of tilapia filleting (head, spine, viscera, abdominal fat and fins).

However, since ingredients such as TFWM are by-products, they differ in their chemical and energetic compositions due to the physico-chemical composition of the feedstock and the differential processing used to obtain the meal. These changes may ultimately alter results on the performance (EYNG et al., 2010).

The objective of this research was to accomplish a nutritional evaluation of TFWM in barrows from 15 to $30 \mathrm{~kg}$.

\section{MATERIAL AND METHODS}

Three experiments were carried out at the Experimental Farm of Universidade Estadual do Oeste do Paraná - UNIOESTE, Campus of Marechal Cândido Rondon, Paraná State, Brazil. The materials and methods used in these experiments were approved by the Animal Care and Use Committee of UNIOESTE, under protocol number 061/2012.

In the first experiment, the chemical composition and energy of TFWM were determined. Ten crossbred barrows (Pietráin x Landrace x Large White) with an average body weight of $15.10 \pm 0.74$ $\mathrm{kg}$ were used in this study. The animals were individually housed in stainless-steel cages for metabolic studies similar to those described by Pekas (1968).
The experimental design was completely randomized, with two treatments and five replicates. The metabolism assay used a seven day adjustment period, followed by a five day period of total collection of feces and urine, according to the methodology of Fialho et al. (1979). Barrows were fed twice a day (07:00 and 19:00 hours) based on their metabolic weight (Body Weight $-\mathrm{BW}^{0.75}$ ) and the ration remained at the feeder until total intake. Water was freely offered after each feeding.

The TFWM replaced $20 \%$ of the reference diet, based on corn (72.66\%), soybean meal $(23.22 \%)$, vitamins and minerals, amino acids and additives, formulated to meet the nutritional requirements proposed by Rostagno et al. (2011).

Chemical analyses of TFWM, besides experimental diets, feces and urine were held at the Animal Nutrition Laboratory of UNIOESTE, according to techniques described by Silva and Queiroz (2002). Dry matter (DM) , crude protein (CP), ether extract (EE), mineral matter (MM), calcium (Ca), phosphorus (P) and gross energy (GE). The energy composition of TFWM and its digestible energy (ED), metabolizable energy (ME), digestibility coefficient of gross energy (DCGE) and metabolizable coefficient of gross energy (MCGE) were determined using equations proposed by Matterson et al. (1965).

In the second experiment, the ileal digestibility coefficients of essential amino acids contained in the TFWM were determined. A total of 10 crossbred barrows (Landrace $\mathrm{x}$ Large White $\mathrm{x}$ Pietrain) with an initial body weight of $15.00 \pm 0.27$ $\mathrm{kg}$ were individually housed in stainless-steel cages for metabolic studies similar to those described by Pekas (1968).

Animals were submitted to a five day adaptation period. On the seventh day, digesta were collected from the terminal ileum, according a technique adapted by Apolônio et al. (2002). The experimental design was completely randomized with two treatments and five replicates. Each treatment consisted of a basal diet in which TFWM was the only source of protein and amino acids, and a free protein diet (FPD), in order to determine the loss of endogenous amino acids and calculate the ileal amino acid digestibility. The FPD was formulated to contain the same level of neutral detergent fiber (NDF) as the basal diet. For that, rice hulls were used as a source of NDF. The basal diet was formulated to meet the nutritional requirements proposed by Rostagno et al. (2011). The only source of protein and amino acids included in this ration was TFWM. The compositions of the basal diet and FPD are described in Table 1. 
Table 1. Ingredients and chemical and energetic composition of basal (BASAL) and free protein diet (FPD) for barrows from 15 to $30 \mathrm{~kg}$.

\begin{tabular}{|c|c|c|}
\hline Ingredients & BASAL (\%) & FPD (\%) \\
\hline TFWM $^{1}$ & 33.80 & - \\
\hline Sugar & 38.00 & 21.00 \\
\hline Starch & 20.00 & 70.03 \\
\hline Rice hulls & 5.06 & 5.07 \\
\hline Soy oil & 2.11 & 0.00 \\
\hline Dicalcium phosphate & 0.000 & 1.924 \\
\hline Limestone & 0.000 & 0.687 \\
\hline Salt & 0.000 & 0.319 \\
\hline Vitamin supplement $t^{2}$ & 0.100 & 0.100 \\
\hline Mineral supplement ${ }^{3}$ & 0.050 & 0.050 \\
\hline Growth promoter ${ }^{4}$ & 0.020 & 0.020 \\
\hline Antioxidant ${ }^{5}$ & 0.010 & 0.010 \\
\hline Sodium bicarbonate & 0.350 & 0.290 \\
\hline Chromic oxide & 0.500 & 0.500 \\
\hline Total & 100.00 & 100.00 \\
\hline \multicolumn{3}{|c|}{ Composition } \\
\hline Dry Matter (\%) & 92.66 & 90.73 \\
\hline NDF (\%) & 4.227 & 4.237 \\
\hline $\operatorname{ADF}(\%)$ & 2.723 & 2.728 \\
\hline $\mathrm{ME}(\mathrm{kcal} / \mathrm{kg})$ & 3,230 & 3,230 \\
\hline Crude protein $(\%)$ & 18.13 & - \\
\hline Calcium (\%) & 2.610 & 0.733 \\
\hline Available phosphorus (\%) & 1.302 & 0.363 \\
\hline Sodium $(\%)$ & 0.219 & 0.205 \\
\hline Chlorine $(\%)$ & 0.304 & 0.190 \\
\hline Potassium (\%) & 0.166 & - \\
\hline SID Lysine (\%) & 0.919 & - \\
\hline SID Threonine (\%) & 0.714 & - \\
\hline SID Met + Cys $(\%)$ & 0.602 & - \\
\hline SID Methionine (\%) & 0.328 & - \\
\hline
\end{tabular}

${ }^{1}$ Tilapia filleting waste meal. ${ }^{2}$ Content $/ \mathrm{kg}: 10,000,000 \mathrm{IU}$ vit $\mathrm{A}, 1,500,000 \mathrm{IU}$ vit $\mathrm{D}, 30,000 \mathrm{IU}$ vit E, $2.0 \mathrm{~g}$ vit $\mathrm{B}_{1}, 5.0 \mathrm{~g}$ vit $\mathrm{B}_{2}, 3.0 \mathrm{~g}$ vit. $\mathrm{B}_{6}, 30,000 \mathrm{mcg}$ vit $\mathrm{B}_{12}, 30,000 \mathrm{mcg}$ nicotinic acid, $12,000 \mathrm{mcg}$ pantothenic acid, 2,000 mg vit. $\mathrm{K}_{3}, 800 \mathrm{mg}$ folic acid, $100 \mathrm{mg}$ biotin, $300 \mathrm{mg}$ selenium, and QSAD vehicle for $1000 \mathrm{~g}$. ${ }^{3}$ Content $/ \mathrm{kg}$ : $100 \mathrm{~g}$ iron, $10 \mathrm{~g} \mathrm{copper,} 1 \mathrm{~g}$ cobalt, $40 \mathrm{~g}$ manganese, $100 \mathrm{~g}$ zinc, $1.5 \mathrm{~g}$ iodine, and QSAD vehicle for $1000 \mathrm{~g}$. ${ }^{4}$ Tilosin phosphate. ${ }^{5}$ BHT.

Both experimental diets contained $0.5 \%$ chromic oxide $\left(\mathrm{Cr}_{2} \mathrm{O}_{3}\right)$, which was used as an external marker to determine digestibility. The amount of feed provided per pig per meal during the experiment was calculated on the basis of metabolic body weight $\left(\mathrm{BW}^{0.75}\right)$. The barrows were fed at 07:00 $\mathrm{h}$ and 19:00 $\mathrm{h}$ each day. Water was freely offered after each feeding.

An experimental protocol was conducted to determine the ideal time for collection of digesta, in which part of the diet was found in the stomach and part in the large intestine. A $24 \mathrm{~h}$ fasting period was instigated prior to the animals being fed. Digesta was then collected three hours later.

Animals were slaughtered by neck stunning, followed by heart perforation and fast bleeding. Shortly after, the abdominal cavity was opened by ventral incision. The ileum segment was exteriorized and the passage of digesta between the ileocecal valve and the end of the ileocecal fold was obstructed with hemostatic forceps. A segment of approximately $20 \mathrm{~cm}$ was removed, washed with distilled water and dried with paper towel for digesta occlusion. The aliquots of five animals from each feeding were combined to form a pool sample.
Rations and part of each digesta sample were used to perform analyses of dry matter, crude protein and chromic oxide at the Animal Nutrition Laboratory of Unioeste, according to the methodologies described by Silva and Queiroz (2002).

The remaining digesta samples were stored in plastic bags at $-10{ }^{\circ} \mathrm{C}$, and subsequently homogenized and lyophilized. The amino acid composition in the feeds (TFWM and rice hulls), rations and digesta were determined by high performance liquid chromatography at Evonik Industries AG Feed Additives, Germany.

Apparent ileal digestibility and true of amino acids in the basal diet were determined. These parameters were calculated based on the levels of chromium $(\mathrm{Cr})$ in the diets and digesta, by calculating the indigestible factor (IF) according to equations proposed by Sakomura and Rostagno (2007).

In the third experiment, we evaluated the performance of pigs fed diets containing different concentrations of TFWM. Forty barrows with an initial weight of $15.00 \pm 0.87 \mathrm{~kg}$ were distributed in a complete randomized block design, with four treatments $(5,10,15$ and $20 \%$ of TFWM inclusion) and a group control, four replicates and two animals 
per experimental unit, housed in nursery pens.

The experimental diets (Table 2) were formulated to ensure they met the minimum recommendations of Rostagno et al. (2011), using the values of metabolizable energy and SID amino acids determined in experiments 1 and 2.

Table 2. Ingredients and chemical and energetic composition of diets containing different TFWM concentrations for barrows from 15 to $30 \mathrm{~kg}$.

\begin{tabular}{|c|c|c|c|c|c|}
\hline \multirow{2}{*}{ Ingredients (\%) } & \multicolumn{5}{|c|}{ TFWM inclusion levels (\%) } \\
\hline & 0 & 5 & 10 & 15 & 20 \\
\hline Corn & 68.86 & 71.99 & 72.97 & 73.12 & 73.52 \\
\hline Soybean meal & 26.51 & 19.61 & 13.01 & 6.80 & 0.54 \\
\hline TFWM & 0.00 & 5.00 & 10.00 & 15.00 & 20.00 \\
\hline Soy oil & 0.735 & 0.077 & 0.130 & 0.270 & 0.588 \\
\hline Monocalcium phosphate & 1.434 & 0.602 & 0.000 & 0.000 & 0.000 \\
\hline Limestone & 1.043 & 0.607 & 0.045 & 0.000 & 0.000 \\
\hline Sodium bicarbonate & 0.520 & 0.803 & 1.081 & 1.341 & 1.605 \\
\hline Antioxidant ${ }^{2}$ & 0.010 & 0.010 & 0.010 & 0.010 & 0.010 \\
\hline Salt & 0.103 & 0.009 & 0.000 & 0.000 & 0.000 \\
\hline Mineral supplement ${ }^{3}$ & 0.050 & 0.050 & 0.050 & 0.050 & 0.050 \\
\hline Vitamin supplement ${ }^{4}$ & 0.100 & 0.100 & 0.100 & 0.100 & 0.100 \\
\hline L-Lysine $\mathrm{HCl}$ & 0.385 & 0.471 & 0.551 & 0.620 & 0.691 \\
\hline DL-Methionine & 0.105 & 0.121 & 0.139 & 0.155 & 0.172 \\
\hline L-Threonine & 0.102 & 0.131 & 0.160 & 0.185 & 0.212 \\
\hline L-Tryptophan & 0.012 & 0.032 & 0.052 & 0.070 & 0.088 \\
\hline L-Valine & 0.014 & 0.049 & 0.084 & 0.113 & 0.144 \\
\hline Inert $^{5}$ & 0.000 & 0.319 & 1.501 & 2.060 & 2.128 \\
\hline Growth promoter ${ }^{6}$ & 0.020 & 0.020 & 0.020 & 0.020 & 0.020 \\
\hline Total & 100.00 & 100.00 & 100.00 & 100.00 & 100.00 \\
\hline \multicolumn{6}{|c|}{ Composition } \\
\hline Dry Matter (\%) & 89.29 & 89.37 & 89.62 & 90.03 & 90.43 \\
\hline Metabolizable energy (kcal/kg) & 3,230 & 3,230 & 3,230 & 3,230 & 3,230 \\
\hline Crude protein $(\%)$ & 19.24 & 19.24 & 19.24 & 19,24 & 19.24 \\
\hline Calcium & 0.768 & 0.768 & 0.768 & 1.085 & 1.419 \\
\hline Available phosphorus (\%) & 0.380 & 0.380 & 0.424 & 0.587 & 0.749 \\
\hline Sodium $(\%)$ & 0.200 & 0.257 & 0.346 & 0.434 & 0.522 \\
\hline Potassium (\%) & 0.686 & 0.593 & 0.500 & 0.412 & 0.322 \\
\hline Chlorine (\%) & 0.190 & 0.194 & 0.246 & 0.302 & 0.357 \\
\hline SID Lysine (\%) & 1.093 & 1.093 & 1.093 & 1.093 & 1.093 \\
\hline SID Met+Cys (\%) & 0.612 & 0.612 & 0.612 & 0.612 & 0.612 \\
\hline SID Methionine (\%) & 0.349 & 0.371 & 0.393 & 0.414 & 0.436 \\
\hline SID Threonine (\%) & 0.689 & 0.689 & 0.689 & 0.689 & 0.689 \\
\hline SID Tryptophan (\%) & 0.197 & 0.197 & 0.197 & 0.197 & 0.197 \\
\hline SID Valine (\%) & 0.754 & 0.754 & 0.754 & 0.754 & 0.754 \\
\hline $\mathrm{DEB}(\mathrm{mEq} / \mathrm{kg})^{7}$ & 208.81 & 208.68 & 208.92 & 208.88 & 208.60 \\
\hline
\end{tabular}

${ }^{1}$ Tilapia filleting waste meal. ${ }^{2}$ BHT. ${ }^{3}$ Content $/ \mathrm{kg}$ : $100 \mathrm{~g}$ iron, $10 \mathrm{~g}$ copper, $1 \mathrm{~g}$ cobalt, $40 \mathrm{~g}$ manganese, $100 \mathrm{~g}$ zinc, $1.5 \mathrm{~g}$ iodine, and QSAD vehicle for $1000 \mathrm{~g}$. ${ }^{4}$ Content $/ \mathrm{kg}$ : $10,000,000 \mathrm{IU}$ vit. A, 1,500,000 IU vit $\mathrm{D}_{3}, 30,000 \mathrm{IU}$ vit. E, $2.0 \mathrm{~g}$ vit $\mathrm{B}_{1}, 5.0 \mathrm{~g}$ vit $\mathrm{B}_{2}, 3.0 \mathrm{~g}$ vit. $\mathrm{B}_{6}, 30,000 \mathrm{mcg}$ vit $\mathrm{B}_{12}, 30,000 \mathrm{mcg}$ nicotinic acid, $12,000 \mathrm{mcg}$ pantothenic acid, 2,000 mg vit. $\mathrm{K}_{3}, 800 \mathrm{mg}$ folic acid, $100 \mathrm{mg}$ biotin, $300 \mathrm{mg}$ selenium, and QSAD vehicle for $1000 \mathrm{~g} .{ }^{5}$ Fine clean sand. ${ }^{6}$ Tilosin phosphate. ${ }^{7}$ Dietary electrolyte balance.

Animals were weighed at the beginning and end of the experiment to determine the initial (IW) and final (FW) weights, and the average daily gain (ADG). Diets were weighed when given to animals, to determine the daily feed intake (DFI) and feed conversion (FC).

Data were subjected to statistical analysis by the Statistical and Genetic Analysis System - SAEG (FEDERAL UNIVERSITY OF VIÇOSA, 1999). Performance data were submitted to analysis of variance (ANOVA). The means of performance variables related to different concentrations of
TFWM were compared to the control group using Dunnett's test $(5 \%)$. Subsequently, the degree of freedom related to TFWM concentrations was broken for polynomial regression, according to the adjustment obtained for each parameter. Significance was declared at $\mathrm{P}<0.05$.

\section{RESULTS AND DISCUSSION}

The values of dry matter $(95.28 \%)$, gross energy $(4,658 \mathrm{kcal} / \mathrm{kg})$ and mineral matter $(23.42 \%)$ 
within TFWM (Table 3) were similar to those found by Eyng et al. (2010), which corresponded to $93.74 \%, 4,778 \mathrm{kcal} / \mathrm{kg}$, and $23.64 \%$, respectively, in a residue from the same origin as the by-product evaluated in this study.

Table 3. Chemical composition and energetic values (mean \pm SD) of TFWM $^{1}$ expressed in natural matter for barrows from 15 to $30 \mathrm{~kg}$.

\begin{tabular}{lc}
\hline Variables & Values \\
\hline Dry matter (\%) & 95.28 \\
Crude protein (\%) & 53.46 \\
Ether extract (\%) & 16.82 \\
Mineral matter (\%) & 23.42 \\
Calcium (\%) & 6.98 \\
Phosphorus (\%) & 3.52 \\
Gross energy (kcal/kg) & $4,658 \pm 123.89$ \\
Digestible energy (kcal/kg) & $3,632 \pm 154.46$ \\
Metabolizable energy (kcal/kg) & $3,260 \pm 142.37$ \\
ME:DE & 89.76 \\
CDEB $(\%)$ & $77.98 \pm 2.73$ \\
CMEB $^{3}(\%)$ & $69.98 \pm 4.15$ \\
\hline
\end{tabular}

${ }^{1}$ Tilapia filleting waste meal. ${ }^{2}$ DCGE: digestibility coefficient of gross energy. ${ }^{3}$ MCGE: metabolizability coefficient of gross energy.

According to Geron et al. (2006), excess mineral content present in fish meal waste derived from pickle industries results in low protein content, since the mineral matter (especially calcium and phosphorus) dilutes the concentration of macromolecules (proteins and lipids) present in the meat. However, this was not observed in the present study, given that the crude protein level of TFWM was $53.46 \%$; higher than the $45.23 \%$ reported by Eyng et al. (2010). The above authors found $68.6 \%$ moisture, $42.9 \%$ crude protein, $34.6 \%$ lipids and $16.3 \%$ mineral matter ( $\%$ of dry matter) in tilapia waste - all values which were lower than those found in this study.

The $\mathrm{Ca}$ and $\mathrm{P}$ levels found in this study were 6.98 and $3.52 \%$ and are close to the 7.71 and $3.83 \%$, respectively, reported by Eyng et al. (2010) in TFWM from the same origin, but were higher than those reported by Rostagno et al. (2011), (5.88 and $2.89 \%$ respectively) in a fish meal with $54 \% \mathrm{CP}$.

In the case of TFWM, Boscolo et al. (2004) stated that one of the characteristics of this food is the high content of $\mathrm{Ca}$ and $\mathrm{P}$; however, despite the fact that the high amount of ash is a limiting factor for the use of this waste, this food can be used as a source of minerals, which is why the determination of its nutritional profile is essential.

The fat content of the TFWM was $16.82 \%$, higher than that reported in the literature by Boscolo et al. (2004) (10.35\%) who analyzed the same meal and Rostagno et al. (2011) $(7.46 \%)$ who analyzed industrial fish meal with $54 \% \mathrm{CP}$.

In our study, the GE, DE and ME values corresponded to 4,658, 3,632 and 3,260 kcal/ $\mathrm{kg}$, and were higher than the values of $4,065,3,050$ and $2,740 \mathrm{kcal} / \mathrm{kg}$, respectively, reported by Rostagno et al. (2011). Similarly, the DE and ME values proposed by NRC (2012) - 3,770 and 3,360 kcal/kg, respectively - are higher than those obtained in this study. However, in this work, meal was composed exclusively of tilapia and nonstandard was evaluated, while the cited authors evaluated meals composed of waste from different fish species, and standardized (54\% and $62.3 \% \mathrm{CP}$, respectively).

In this study, the pigs took about $78 \%$ of the EB from the TFWM as DE and about $70 \%$ as ME. Furthermore, the ME:DE ratio was approximately $90 \%$. The determination of the ME:DE ratio is important to illustrate the degree of energy loss via urine, given that high protein levels in the diet can contribute to increased nitrogen excretion in urine, increasing the gross energy in urine and reducing the ME:DE ratio of the diet. Noblet and Perez (1993) observed that the ME:DE ratio is reduced by $2 \%$ for each $1 \%$ increase in dietary CP. This is due to increased protein catabolism, which is in excess.

The values of DCGE and MCGE in the present study (77.98 and $69.98 \%$, respectively) were similar to the values of 75.03 and $67.40 \%$, respectively, obtained by Rostagno et al. (2011). The variation observed in the metabolizability coefficients can be assigned to different processes to which feed are subjected. The temperature required for the elimination of pathogens present in the waste meal is typically high. This provides high temperature reactions between nutrients, which can form complexes or cause protein denaturation, ultimately rendering these nutrients indigestible and decreasing the energy value of the food (Butolo, 2002).

The endogenous amino acid excretion did not provide the same profile for all essential amino acids. Histidine and methionine showed the lowest endogenous loss ( $7 \mathrm{mg} / \mathrm{kg}$ of FPD consumed for both), whereas leucine and threonine showed the highest concentration of endogenous loss (33 and 28 
$\mathrm{mg} / \mathrm{kg}$ of FPD consumed, respectively) (Table 4). Pozza et al. (2005) obtained a similar result for threonine, reporting $0.27 \mathrm{~g} / \mathrm{mg}$ of endogenous loss.

The endogenous loss of amino acids observed varied greatly in relation to those reported in the literature. A significant endogenous loss of threonine was observed, which may be related to the increase in glycoproteins present in the intestinal mucus, which contains high levels of this amino acid (GRALA et al., 1998). According to Fan and Sauer (1995) the mucin layer has large amounts of threonine, with great endogenous losses.

Table 4. Ileal endogenous amino acids (IEAA) determined using a free protein diet (FPD), total amino acids (TAA), apparent (AIDAA) and standardized ileal digestible amino acids (SIDAA), apparent ileal digestibility coefficient (AIDC) and standardized ileal digestibility coefficient (SIDC) of essential amino acids from TFWM ${ }^{1}$

\begin{tabular}{lcccccc}
\hline Essential amino acids & $\begin{array}{c}\text { IEAA } \\
(\mathrm{mg} / \mathrm{kg} \text { FPD } \text { intake })\end{array}$ & TAA $(\%)$ & $\begin{array}{c}\text { AIDAA } \\
(\%)\end{array}$ & $\begin{array}{c}\text { SIDAA } \\
(\%)\end{array}$ & $\begin{array}{c}\text { AIDC } \\
(\%)\end{array}$ & $\begin{array}{c}\text { SIDC } \\
(\%)\end{array}$ \\
\hline Arginine & 16 & 3.448 & 2.863 & 2.912 & 83.02 & 84.46 \\
Histidine & 7 & 0.885 & 0.627 & 0.647 & 70.81 & 73.14 \\
Isoleucine & 19 & 1.896 & 1.417 & 1.474 & 74.73 & 77.74 \\
Leucine & 33 & 3.385 & 2.541 & 2.639 & 75.07 & 77.97 \\
Lysine & 16 & 2.719 & 2.035 & 2.083 & 74.84 & 76.60 \\
Methionine & 7 & 0.969 & 0.778 & 0.799 & 80.31 & 82.43 \\
Met.+ Cys. & 14 & 1.782 & 1.074 & 1.116 & 60.28 & 62.65 \\
Phenylalanine & 19 & 1.968 & 1.501 & 1.558 & 76.25 & 79.11 \\
Threonine & 28 & 2.114 & 1.343 & 1.427 & 63.52 & 67.50 \\
Valine & 24 & 2.489 & 1.788 & 1.859 & 71.84 & 74.69 \\
\hline Average & - & - & - & - & 73.07 & 75.63 \\
\hline
\end{tabular}

${ }^{1}$ Tilapia filleting waste meal.

The SIDAA values obtained for essential amino acids are similar to those proposed by Rostagno et al. (2011) for fish meal with 54\% CP. In this study, the amino acids lysine, methionine, Met + Cys, threonine and arginine showed SIDAA values corresponding to $2.083,0.789,1.116,1.427$ and $2.912 \%$, respectively. For these same amino acids, Rostagno et al. (2011) obtained SIDAA values of $2.63,1.00,1.43,1.56$ and $2.81 \%$, respectively.

The SIDC values of the amino acids arginine, lysine, and methionine were 84.46, 76.60 and $82.43 \%$; respectively. However, Cervantes-Pahm and Stein (2010), when evaluating a commercial fish meal for pigs at an early stage, had higher results of SIDC for the same amino acids, corresponding to 94, 87.4 and $89.3 \%$, respectively.

The standardized ileal digestibility coefficient is influenced by the overheating cooking process used to obtain the ingredient, resulting in a reduction in the digestibility of some amino acids such as lysine. It is possible that there was heat excess in the process used for obtaining TFWM. The reduction in quality is due to the formation of disulfide bonds and the consequent increase in the passage of proteins through the gastrointestinal tract (EYNG et al., 2010). According to Furuya et al. (2001), the heat treatment used for the preparation of industrial waste filleting fish meal can lead to the unavailability of amino acids, especially lysine.

Table 5 presents the values of growth performance for barrows from 15 to $30 \mathrm{~kg}$ fed diets containing different concentrations of TFWM. Levels of TFWM from 0 to $10 \%$ did not affect the FBW and ADWG of pigs $(P<0.05)$, but upon inclusion of $15 \%$ TFWM in the feed, there was a decrease in the values of both FBW and ADWG.

Table 5. Growth performance of barrows (15 to $30 \mathrm{~kg}$ ) fed diets containing different levels of TFWM ${ }^{1}$.

\begin{tabular}{|c|c|c|c|c|c|c|c|c|}
\hline \multirow{2}{*}{ Variables $^{2}$} & \multicolumn{5}{|c|}{ TFWM levels (\%) } & \multirow{2}{*}{$\begin{array}{c}P \\
\text { linear }\end{array}$} & \multirow{2}{*}{$P$ quadratic } & \multirow{2}{*}{$\mathrm{CV}(\%)$} \\
\hline & 0 & 5 & 10 & 15 & 20 & & & \\
\hline IBW (kg) & 15.16 & 15.19 & 15.14 & 15.27 & 15.20 & - & - & 0.79 \\
\hline $\mathrm{FBW}(\mathrm{kg})^{3}$ & 34.11 & 31.88 & 30.65 & $29.96^{*}$ & $28.38 *$ & 0.01 & 0.08 & 7.77 \\
\hline ADWG (g) & 666 & 587 & 545 & $514^{*}$ & $462 *$ & 0.01 & 0.07 & 14.85 \\
\hline ADFI (kg) & 1.13 & 0.99 & 0.99 & 0.94 & 0.88 & - & - & 11.83 \\
\hline$F: G$ & 1.69 & 1.70 & 1.83 & 1.83 & $1.91 *$ & 0.01 & 0.07 & 6.08 \\
\hline
\end{tabular}

${ }^{1}$ TFWM: Tilapia filleting waste meal. ${ }^{2}$ IBW: initial body weight, FBW: final body weight; ADWG: average daily weight gain; ADFI: average daily feed intake; F:G: feed gain ratio. ${ }^{3}$ Average values in lines followed by $*$ differ $(P<0.05)$ from control treatment by Dunnett test.

Lopes et al. (2004) compared the performance of barrows from 6 to $15 \mathrm{~kg}$ fed conventional diets or $6 \%$ fish meal inclusion substituted for powdered whey, and observed that the diet containing fish meal provided an ADWG of $370 \mathrm{~g}$ versus $356 \mathrm{~g}$ for the conventional diet.

The linear decrease in ADWG values as a function of increasing dietary levels of TFWM could 
be explained by the potential loss of nutrients in the feed after its industrial processing. According to Furuya et al. (2001), the heat treatment used for the preparation of industrial filleting waste fish meal can lead to a loss of amino acids, especially lysine due to its smaller resistance to the Maillard reaction, making this amino acid unavailable in the feed. Beyond that, the ADFI, although not statistically different $(P>0.05)$ decreased over all the treatments evaluated, with a $22 \%$ reduction between the highest and lowest concentrations of TFWM in the diet.

The means of the $\mathrm{F}: \mathrm{G}$ ratio differed $(P<0.05)$ only at the highest concentration of TFWM in relation to the reference diet. For this concentration $(20 \%$ TFWM) there was an increase in $\mathrm{F}: \mathrm{G}$ representing a worsening in the performance of the pigs.

Similarly, Junqueira et al. (2008) obtained a F:G ratio of 1.78 when $5 \%$ fish meal replaced soybean meal in the diets of pigs from 8 to $20 \mathrm{~kg}$. Animals that received the basal diet presented a $F: G$ ratio of 1.66; which allowed the authors to conclude that the inclusion of $5 \%$ fish meal significantly damaged the $F: G$ ratio of the pigs.

There was a decreasing linear effect of TFWM concentrations on FBW $(P=0.01)$, which produced the regression equation $\hat{\mathrm{Y}}=33.675-$ $0.268 \mathrm{X}\left(\mathrm{R}^{2}=0.44\right)$; as well as $\operatorname{ADWG}(P=0.01)$, which produced the regression equation $\hat{\mathrm{Y}}=$ $0.651282-0.009639 X\left(\mathrm{R}^{2}=0.46\right)$. For the $\mathrm{F}: \mathrm{G}$ ratio, there was an increasing linear effect $(P=0.01)$, resulting in the following regression equation: $\hat{\mathrm{Y}}=$ $1.67971+0.0112058 X\left(\mathrm{R}^{2}=0.39\right)$. Although the correlation coefficients were low for the above variables, the shelf life of the feed may have contributed to the poor performance of the pigs as the TFWM concentrations increased. The feed was stored for nearly 10 months between its production and its use in these experiments. According to Anderson et al. (1993), preservation of raw material can influence the protein quality, because long term storage can cause degradation of amino acids by bacterial activity, resulting in the production and accumulation of biogenic amines.

\section{CONCLUSIONS}

TFWM presented digestible and metabolizable energy values corresponding to 3,632 and $3,260 \mathrm{kcal} / \mathrm{kg}$, respectively, for crossbred barrows from 15 to $30 \mathrm{~kg}$.

The average coefficients of apparent and true ileal digestibility of essential amino acids in TFWM corresponded to $73.07 \%$ and $75.63 \%$; respectively. The true ileal digestible amino acid values were $2.083 \%, 1.427 \%, 1.116 \%$ and $0.799 \%$, for lysine, threonine, met + cys and methionine, respectively.

The inclusion of up to $10 \%$ TFWM in the diets of barrows from 15 to $30 \mathrm{~kg}$ did not reduce
GPD and CA.

\section{REFERENCES}

ANDERSON, J. S.; LALL, S. P.; McNIVEN, M. A. Evaluation of protein quality of fish meal by chemical and biological assays. Aquaculture, Amsterdam, v. 115, n. 3, p. 305-325, 1993.

APOLÔNIO, L. D. et al. Digestibilidade ileal de aminoácidos de alimentos utilizados em dietas préiniciais para leitões, determinada pelo método do sacrifício. Revista Brasileira de Zootecnia, Viçosa, v. 31, n. 5, p. 1983-1992, 2002.

BOSCOLO, W. R.; HAYASHI, C.; MEURER, F. Digestibilidade aparente da energía e proteína das farinhas de residuo da filetagem da tilápia do Nilo (Oreochromis niloticus) e da corvina (Plagioscion squamosissimus) e farinha integral do camarão canela (Macrobrachium amazonicum) para a tilápia do Nilo. Revista Brasileira de Zootecnia, Viçosa, v. 33, n. 1, p. 8-13, 2004.

BUTOLO, J. E. Qualidade de ingredientes na alimentação animal. Campinas, SP: Colégio Brasileiro de Nutrição Animal, 2002. 430 p.

CERVANTES-PAHM, K.; STEIN. H. Ileal digestibility of amino acids in conventional, fermented, and enzyme-treated soybean meal and in soy protein isolate, fish meal, and casein fed to weanling pigs. Journal of Animal Science, Champaign, v. 88, n. 8, p. 2674-2683, 2010.

EYNG, C. et al. Farinha de resíduos da indústria de filetagem de tilápias em rações para frangos de corte. Revista Brasileira de Zootecnia, Viçosa, v. 39, n. 12, p. 2670-2675, 2010.

FAN, M. Z.; SAUER, W. C. Determination of apparent ileal amino acid digestibility in barley and canola meal for pigs with the direct, difference, and regression methods. Journal of Animal Science, Champaign, v. 73, n. 8, p. 2364-2374, 1995.

FIALHO, E. T.; ROSTAGNO, H. S.; FONSECA, J. B. Efeito do peso vivo sobre o balanço energético e proteico de rações à base de milho e sorgo com diferentes conteúdos de tanino para suínos. Revista Brasileira de Zootecnia, Viçosa, v. 8, n. 3, p. 396397, 1979.

FURUYA, W. M. et al. Coeficientes de digestibilidade e valores de aminoácidos digestíveis de alguns ingredientes para tilápia do Nilo (Oreochromis niloticus). Revista Brasileira de Zootecnia, Viçosa, v. 30, n. 4, p. 1143-1149, 2001. 
GERON, L. J. V. et al. Digestibilidade e parâmetros ruminais de rações contendo silagens de resíduo da filetagem de tilápia. Acta Scientiarum. Animal Sciences, Maringá, v. 28, n. 4, p. 437-445, 2006.

GRALA, W. et al. Ileal apparent protein and amino acid digestibilities and endogenous nitrogen losses in pigs fed soybean a rapeseed products. Journal of Animal Science, Champaign, v. 76, n. 2, p. 557-568, 1998.

JUNQUEIRA, O. M. et al. Avaliação de níveis e fontes de proteína na alimentação de leitões na fase inicial de crescimento. Revista Brasileira de Zootecnia, Viçosa, v. 37, n. 9, p. 1622-1627, 2008.

LOPES, E. L. et al. Fontes e níveis de proteína em rações iniciais para leitões desmamados aos 21 dias de idade. Revista Brasileira de Zootecnia, Viçosa, v. 33, n. 6, p. 2292-2299, 2004.

MATTERSON, L. D. et al. Research Report 7: The metabolizable energy of feed ingredients for chickens. Hartford, CT: Res. Rep. Conn. Agric. Exp. Stn., 1965. 11 p.

NOBLET, J., PEREZ, J. M. Prediction of digestibility of nutrients and energy values of pig diets from chemical analysis. Journal of Animals Sciences, Champaign, v. 71 , n. 12, p. 3389-3398, 1993.

NATIONAL RESEARCH COUNCIL-NRC. Nutrient requirements of swine. 11Ed, Washington, D.C.: National Academic of Science, 2012, 400 p.

PEKAS, J. C. Versatile swine laboratory apparatus for physiology and metabolic studies. Journal of Animal Science, Champaign, v. 27, n. 2, p. 13031306, 1968.

POZZA, P. C. et al. Digestibilidades ileal aparente e verdadeira dos aminoácidos de farinhas de vísceras para suínos. Revista Brasileira de Zootecnia, Viçosa, v. 34, n. 6, p. 2327-2334, 2005.

RICHTER, N.; SIDDHURAJU, P.; BECKER, K. Evaluation of nutritional quality of moringa (Moringa oleifera Lam.) leaves as an alternative protein source for Nile tilapia (Oreochromis niloticus L.). Aquaculture, Amsterdam, v. 217, n. 2, p. 599$611,2003$.

ROSTAGNO, H. S. et al. Tabelas brasileiras para aves e suínos; composição de alimentos e exigências nutricionais. 3ed. Viçosa, MG: UFV, 2011, 252 p. de pesquisa em nutrição de monogástricos Jaboticabal, SP: FUNEP, 2007. 283 p.

SCHEUERMANN, G. N.; ROSA, P. S. Farinhas de origem animal na alimentação de monogástricos: a qualidade dos produtos define seu potencial de utilização, 2008. Disponível em: <www.agrosoft.org.br/agropag/100285.htm>.

Acesso em: 21 jan. 2016.

SILVA, D. J.; QUEIROZ, A. C. Análise de alimentos: métodos químicos e biológicos. 3. ed. Viçosa, MG: UFV, 2002. 235 p.

UNIVERSIDADE FEDERAL DE VIÇOSA. SAEG - Sistema para análise estatística e genética. Viçosa, MG: 1999. 59 p. 